\title{
Use and valorization of Organic Fraction of Municipal Solid Waste in Colombia for sustainable development
}

José Alejandro Martínez S. *

Fecha de recepción: 13 de septiembre de 2013

Fecha de aprobación: 20 de octubre de 2013

Pp. 243 a 254

\section{RESUMEN}

Los Residuos Sólidos Municipales, son un nuevo objetivo de las administraciones municipales debido a las consecuencias negativas que trae su manejo y gestión inadecuados: problemas de salud, contaminación, etc. En Colombia, la práctica más utilizada para el manejo de los residuos sólidos municipales es la disposición final en rellenos sanitarios, sin embargo, no todos los residuos que se disponen son no aprovechables: (a) la fracción inorgánica que no tuvo separación en la fuente, pierde su posibilidad de incorporarse en cadenas de valor; (b) la fracción orgánica, que se produce durante la preparación de alimentos en casas, restaurantes y empresas, tiene usos potenciales como el abono, que es el más tradicional u otros procesos que usan dicho material como inicio. Este artículo busca explicar dos posibilidades de uso y valorización de la Fracción Orgánica de los Residuos Sólidos Municipales (FORSM o FORSU), desde los resultados obtenidos en dos investigaciones realizadas en la Especialización en Gestión de Residuos Sólidos de la Universidad EAN.

\section{Palabras Clave}

Residuos sólidos urbanos, gestión de residuos, sostenibilidad, aprovechamiento, reciclaje.

\footnotetext{
* Master en Ingeniería Ambiental, Universidad Nacional de Colombia. Extract to the presentation "Beneficial use of Municipal Solid Waste in Latin America", it was made in the 106th meeting of the Air and Waste Management Association (AWMA), Chicago (2013).
} 


\section{Use and valorization of Organic Fraction of Municipal Solid Waste in Colombia for sustainable development}

\section{AbSTRACT}

The Municipal Solid Waste has become a new target for the municipal government due to the negative consequences it may bring in case of inadequate management: diseases, pollution, etc. In Colombia, the most frequent action taken is the final disposal in landfill, nevertheless, not all the solid waste is real waste or unusable material: (a) the inorganic fraction that, due to no source separation, loses the possibility to be used and included in value chains, and (b) the organic fraction, which is produced during food processing in houses, restaurants and enterprises, has potential uses such as compost, which is the most traditional one, or new uses as matter for other processes. This paper intends to explain two possibilities for the use and valorization of the Organic Fraction of Municipal Solid Waste (OF$M S W)$, from the research results of two works in the Specialization in Solid Waste Management of the EAN University.

\section{KEY WORDS}

Municipal Solid Waste, Waste Management, Sustainability, Beneficial Use, Recycling. 


\section{Utilisation et valorisation de la matière organique des déchets solides des villes colombiennes en faveur du développement durable}

\section{RÉSUMÉ}

Les déchets solides émanant des centres urbains colombiens sont la nouvelle cible des administrations publiques et des municipalités qui doivent gérer efficacement leurs déchets sous peine de générer des conséquences néfastes pour l'environnement et la population (maladies, pollution, etc.). En Colombie, la solution la plus fréquente pour l'élimination définitive des déchets est leur mise en décharge, même si ces déchets solides ne sont pas tous inutilisables: I) la fraction non organique qui n'a pas été séparée à la source perd son potentiel d'utilisation dans les chaînes de valeur et II) la fraction organique qui est produite au cours de la transformation domestique des aliments, dans les restaurants et les entreprises, est potentiellement utilisable (traditionnellement en tant que composte, même si de nouvelles utilisation apparaissent). Cet article tente d'expliciter deux possibilités d'utilisation et de valorisation de la Fraction Organique des Déchets Solides Municipaux (FODSM) sur la base de travaux de recherche de la spécialisation en gestion des déchets solides de l'Université EAN.

\section{Mots-clés}

Déchets Solides Municipaux, Gestion des Déchets, Développement Durable, Utilisateur, Recyclage. 


\section{Uso e valorização da fracção orgânica dos resíduos municipais sólidos na Colômbia para desenvolvimento sustentável}

\section{Resumo}

Os Resíduos Sólidos Municipais são um novo objetivo das administrações municipais, pelas consequências negativas causadas pelo uso e gestão inadequados (problemas de saúde, contaminação, etc.); na Colômbia, a prática mais utilizada para o tratamento dos Resíduos Sólidos Municipais é o descarte final em depósitos de lixo; contudo, não todos os residuos dispostos são não aproveitáveis: i) A fracção inorgánica que não teve separação na fonte perde a posibilidade ser incorporarada em cadeias de valor, e ii) A Fracção Orgánica, produzida durante a preparação de alimentos em casas, restaurantes e empresas, tem usos potenciais (Compost é o mais tradicional, mas há outros processos que usam este material como inicio). Este artigo explica duas posibilidades de uso e valorização da Fracção Orgánica dos Resíduos Sólidos Municipais (FORSM ou FORSU), a partir dos resultados obtidos em dois investigações realizadas na Especialização em Gestão de Resíduos Sólidos da Universidade EAN.

\section{Palavras-CHave}

Resíduos Sólidos Urbanos, Gestão de Resíduos, Sustentabilidade, Aproveitamento, Reciclagem. 


\section{Introduction}

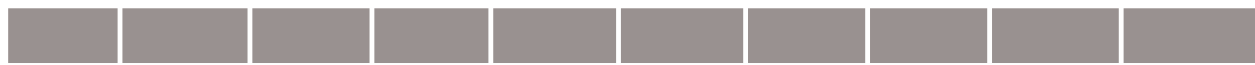

Nen years ago, there were 2.900 million people living in the cities and generating $0,64 \mathrm{~kg}$ of municipal solid waste (MSW), per person per day which is 680 million tonnes per year. As stated in the report What a Waste, A Global Review of Solid Waste Management (World Bank, 2012), this amount is continuously growing. Currently, there are 3.000 million people generating $1,2 \mathrm{~kg}$ of MSW per person per day making 1.300 million tonnes per year. It is possible that by 2025 this amount will have risen up to 4.300 million residents of municipal or urban areas who will generate $1,42 \mathrm{~kg}$ of MSW per person per day meaning 2.200 million tonnes per year. All this MSW will require proper management systems, taking into account the challenge of fulfilling the needs of an industry using new and better materials for products and packaging that after the end of their life cycle will go into the MSW. The inadequate disposal of MSW in a non-technical landfill is a continuous problem since these poor practices can contaminate the elements of the environment: air, soil, superficial and underground water, etc. The leachate generated by the decomposition of the organic fraction of the MSW (OF-MSW) produces contamination due to infiltration and biogas, counted as one of the greenhouse gases (GG) that contributes to global climate change and that is product of microorganism's metabolism and anaerobic decomposition of OF-MSW .

Furthermore, and being aware of the fact that more than $50 \%$ of MSW in Latin America is organic, it is necessary for the communities and the government to come up with different alternatives and options to use MSW's properties in a beneficial way; despite the evident lack of information about the cultural, social, economical, technical and environmental factors that affect the MSW management with a sustainable target. This document is the result of two research projects: one qualitative and the other one quantitative focusing on the possibilities for the beneficial use of MSW in Latin America. Besides the compost process or the earthworm production, the OF-MSW has multiple options for its use such as second generation biofuels production, animal food production, human supplements and 
others. The first research studied the technical and economical feasibility to produce protein for human use; the second research studied the preliminary use of OF-MSW for the production of bioetanol, with laboratory proves and quantitative methodology. Both investigations were made in the solid waste research line of the EAN University in Colombia, with students of the Solid Waste Management specialization, and in the second research with the collaboration of the Universidad de Castilla-La Mancha in Spain.

\section{Overview}

The integral municipal solid waste management is a policy that is currently applied in most countries around the world. This management has phases or stages: rational consumption, selective separation, recollection, transport, storage, beneficial use and valorization, treatment, and disposition of MSW. In Latin America, some stages of this process are not being used due to economical and financial reasons, being the final disposition of MSW in landfills the most important phase for the government. In general, the compounds of the OF-MSW can be transformed into new products with other applications as a way of upcycling, as for example with biomethanization, gasification, hydrogenation, pyrolisis, etc. All these options can be used in multiple applications where energy valorization is the common situation. In accordance with the World Bank (2012), Latin America and the Caribbean have complete information about the solid waste production because of the high frequency of periodic evaluations that are being performed. It is estimated that the total quantity of solid waste in the region is 160 million tonnes per year, with fluctuations between 0.1 to $14 \mathrm{~kg}$ per person per day, and an average of $1.1 \mathrm{~kg}$ per person per day. The highest rate of solid waste generation per capita is located in the Caribbean Islands. 
The composition of MSW varies around the world from region to region, comparing it to the MSW generation index particularly in Latin America, the World Bank last report estimates that the organic fraction of the MSW is the $54 \%$ of the total MSW, reporting paper with $16 \%$ and plastic with $12 \%$, these values corresponding to the poor and middle income countries stated by this Institution (Figure 1).

Figure 1. Average characterization of the MSW in Latin America

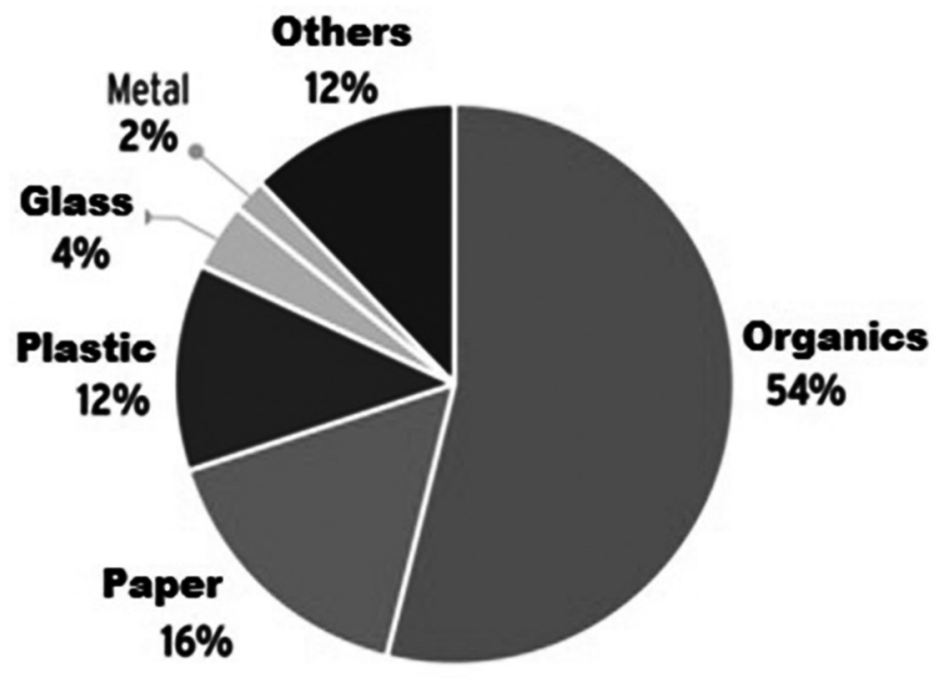

Source. The author, using World Bank data (2012)

This situation demonstrates the importance of applying these new forms in order to increase the value of the OF-MSW in Latin America. Two research studies made between 2011-2012 by the students of the solid waste management specialization, sought to approach this problem with innovative solutions applicable to cities and towns in Latin America. 


\section{Experimental methods}

T

The bioethanol production research was made in the laboratories of Universidad Castilla de la Mancha (UCLM) in Spain, with the objective of evaluating the experimental process to obtain bioethanol from OF- MSW. The methodological design includes the different phases for the evaluation of the biological process. First, we used an artificial mix of solid organic material to simulate OFMSW, with natural products in proportional equivalency to OF-MSW characterization; then, using a bioreactor, we obtained an anaerobic fermentation with Saccharomyces cerevisiae for industrial use. The fermentation was controlled through parameters as $\mathrm{pH}$, temperature, $\mathrm{O} 2$ concentration, and it was monitored with Total Suspend Solids (TSS) and Volatile Suspend Solids (VSS) using standard methods from APHA (Norms 2540 D and $2540 \mathrm{E}$, 1998); for glucose, using the liquid phase chromatography equipment method (HPLC) and for ethanol, using a gas detector chromatography with FID.

The protein production for human consumption research project was a qualitative investigation, and it begun by using the information from solid waste production in Bogotá, continuing with its classification. The following step was to look for information about the valorization options for organic fraction treatment, and compile a lot of data about the compost process, the earthworm production and the protein production for human consumption. With all this information we analyzed the technical and economical feasibility of this process, taking into account weather conditions, temperature and humidity, as well as the technical and economical conditions in Latin America. 


\section{Results and discussion}

Figura 3. Ethanol and Acetone production vs Time

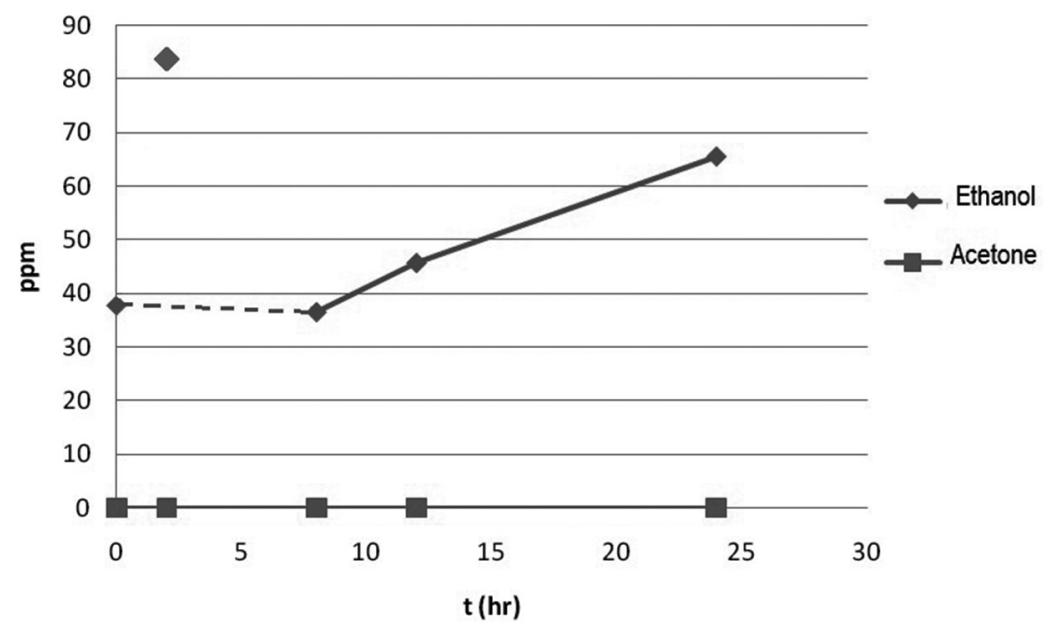

Source. The Author

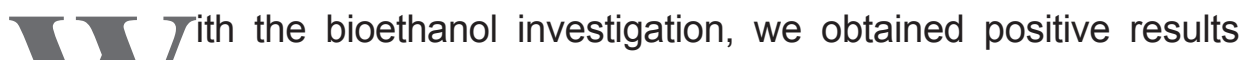
about biofuels production. In Colombia, with prices near to $1,15 \mathrm{USD} /$ liter, the production of bioethanol is a good business since $10 \%$ of the fuel is replaced with bioethanol, and in this research, the comparisons between bioethanol production from glucose fermentation and from OF-MSW fermentation were similar in terms of procedures and equipment used. On average, one day of process is sufficient to obtain concentrations as high as $60 \mathrm{ppm}$ of bioethanol, which represents a high feasibility for this process and scales it to pilot level. For the next steps, it is necessary to increase the number of repetitions in case we want to standardize the process additionally to know and understand the reaction kinetics and the efficiency of the process in relation with the independent variables. Most likely, and in order to increase the efficiency of the reaction, it will be necessary to work on acid digestion or another preparatory phase for the OF-MSW. 
Figura 4. Compost equipment in Mallorga

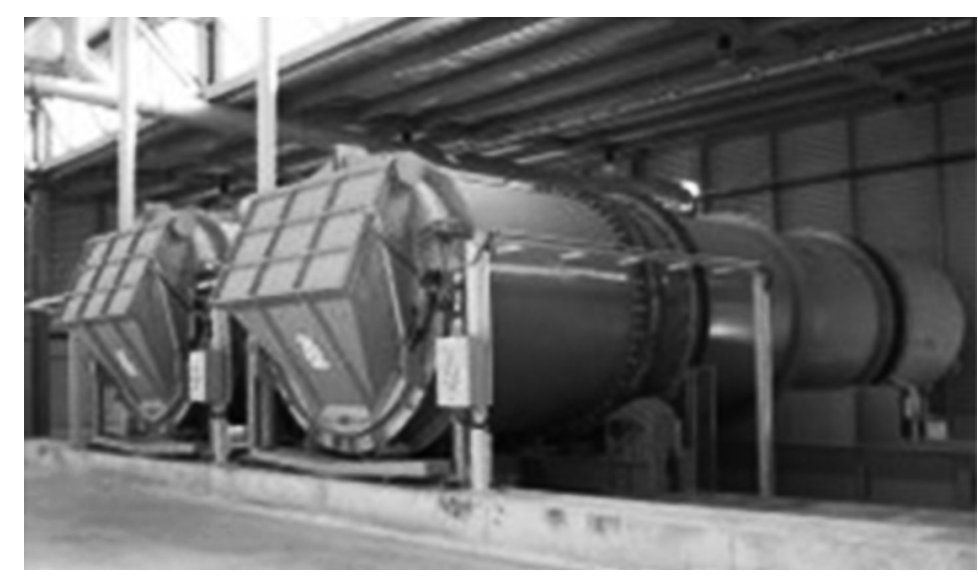

Source. Reciclaje verde.

On the other hand, the OF-MSW process for the production of protein for human consumption demonstrated to have more advantages compared to the traditional landfill management in the ecological, environmental, economical and technical areas. The main process variable is the characterization of the OF-MSW considering that an excess of animal protein in the MSW may generate anaerobic decomposition and toxic sub products for the earthworm (acidification of the environment). After the investigation, the most viable alternative for this process was the aerobic controlled pre-digestion, similar to the compost process, but with the intention of facilitating the earthworm digestion and metabolism. For this study, the infrastructure for processing 2.400 tonnes of hummus per day and 117 tonnes of protein per month will require an initial investment of 300.000 USD. In Colombia, only the disposition of OF-MSW in landfill has a cost of near 62 USD per tonne. 


\section{Summary}

T $\mathrm{n}$ Latin America, it is necessary to evaluate the different options for the management and use of the Municipal Solid Waste (MSW). With

almost 600 million people and an organic fraction of MSW higher than $54 \%$, it is necessary to plan beneficial uses for MSW in order to achieve a successful sustainable development of the countries.

In order to generate solutions to this situation, the solid waste research line of the EAN University in Colombia with the participation of students from the Solid Waste Management Specialization, and the collaboration of the Universidad de Castilla-La Mancha in Spain, made it possible to conduct two research projects about the preliminary beneficial use of OF-MSW for bioethanol production and the technical and economical feasibility of protein production for human use. The results are positive: in the first case, we were able to obtain bioethanol in great proportions using a modified fermentation process; and in the second case, we were able to determine a technical and economical feasibility for the installation and production of earthworm flour as human food supplement. 


\section{References}

Bank, M., (2012). What a Waste: A Global Review of Solid Waste Management. Washington: World Bank.

Boada, A., (2007). Business and sustainability beyond environmental management. Colombia (Original in Spanish): Ed. Politécnico Grancolombiano.

Elías, X., (2009). Industrial Waste Recycling . Madrid (Original in Spanish): Diaz de los Santos.

Gómez, C. y Martínez, J., (2012). Analysis of variables to determine the technical and economic feasibility of obtaining earthworm meal from organic waste. Final research report to obtain the title of specialist in solid waste management (Original in Spanish), 45.

Martínez, J. (2012). Introduction to Solid Waste Management. Specialization in Solid Waste Management (Original in Spanish).

Martínez, S., A, J. y Uribe, A. (2012). Evaluation of an inclusive model for the participation of recyclers based on the implementation of a Technology Park for recycling under the Master Plan for Urban Solid Waste Management in Bogota. Research Direction. Universidad EAN (Original in Spanish).

Mintzberg, H. y Quinn, J., (n.d.). The strategic process of management. Madrid. Spain (Original in Spanish). Prentice Hall.

Montoya, G. y Nancy, J. (2012). Analysis of the Feasibility of obtaining bioethanol from organic fraction of municipal solid waste (MSW). Final research report to obtain the title of specialist in solid waste management (Original in Spanish). Universidad EAN.

Reciclaje verde. (2012). Recuperado de http://reciclajeverde.wordpress.com

Tarzijan, J. ( 2010). Fundamentals of Strategic Management. Alfaomega (Original in Spanish).

Wheelen, T.L., y Hunger, J., (2007). Strategic Management and Business Policy. Mexico: Pearson (Original in Spanish). Tenth Edition. 